\title{
Gramática no Ensino Fundamental: Por uma Pedagogia da reflexão
}

\author{
Ginete Cavalcante Nunes ${ }^{1}$; Maria Aparecida Carvalho Alencar Luz ${ }^{2}$
}

\begin{abstract}
Resumo: Este trabalho objetiva apresentar algumas considerações a respeito do trabalho com a gramática no Ensino Fundamental, acerca da importância do ensino da gramática reflexiva, bem como a significância da sistematização desse ensino no Ensino Fundamental. Objetivamos ainda apresentar algumas considerações sobre o trabalho com gramática no Ensino Fundamental. Para discorrer sobre o tema, utilizou-se como base teórica, os trabalhos de Geraldi (1991), Possenti (1996), Travaglia (2008), entre outros. Sendo assim, este estudo também busca refletir sobre a importância do ensino sistematizado e diferenciado de gramática no Ensino fundamental à partir de gêneros textuais, para a promoção de um processo bem elaborado de ensino e aprendizagem.
\end{abstract}

Palavras- chave: Ensino de Gramática; texto; reflexão.

\section{Grammar in Elementary School: For a Pedagogy of reflection}

\begin{abstract}
This study presents some considerations about the work with the grammar in elementary school, about the importance of reflective teaching grammar as well as the significance of the systematization of this teaching in elementary school. We aim also to present some considerations about working with grammar in elementary school. To discuss the subject, was used as a theoretical basis, the work of Geraldi (1991), Possenti (1996) Travaglia (2008) among others. Thus, this study also seeks to reflect on the importance of systematic and differentiated teaching grammar in elementary education from the genres, to promote a well-designed process of teaching and learning.
\end{abstract}

Key words: grammar teaching; text; reflection.

\section{Introdução}

O ensino de Língua Portuguesa no Ensino Fundamental apresenta algumas características específicas que se relacionam à organização dessa etapa da escolarização quanto à escolha dos conteúdos a serem convertidos em objetos de ensino, quanto à progressão desses objetos nas séries do Ensino Fundamental e quanto às justificativas para se estudar tais tópicos.

\footnotetext{
${ }^{1}$ Graduada em Letras, língua Inglesa, pela Faculdade de Formação de Professores de Araripina - FAFOPA Especialização em Políticas Educativas e Docência do Ensino Superior pela Faculdade de Formação de Professores de Araripina - FAFOPA. Cursando Mestrado Profissional em Letras - PROFLETRAS, pela Universidade Federal Rural de Pernambuco - UFRPE. Docente na Faculdade de Formação de Professores de Araripina - FAFOPA. Autor correspondente. E-mail: ginetecavalcante@bol.com.br;

${ }^{2}$ Graduação em Pedagogia, Supervisão Escolar, pela Faculdade de Ciências Humanas do Sertão Central. Especialista em Gestão Educacional. Docente na Faculdade de Formação de Professores de Araripina - FAFOPA. Analista em Gestão Educacional pela Secretaria Educação de Pernambuco.
} 
Percebe-se que nessa etapa a seleção de objetos têm sido determinantes para o sucesso do processo de ensino e aprendizagem, principalmente no que tange ao ensino de gramática no Ensino fundamental, pois, esse ensino deve ser bem sistematizado para conceder que estes estudantes consigam aprender na aula de língua portuguesa com um ensino sistematizado e agradável de gramática.

Neste trabalho defende-se a idéia que a gramática pode e deve ser ensinada de forma dinâmica e participativa em sala de aula como uma de maneira que os estudantes possam refletir sobre o língua através da gramática contextualizada como passaremos a refletir.

\section{Como Trabalhar a Gramática no Ensino Fundamental?}

Geraldi (1991) diz que o texto é ponto de partida e ponto de chegada de todo processo de ensino e aprendizagem. A língua não está nas regras gramaticais, mas no fluxo da linguagem onde constituem os sujeitos. Corroboramos com Geraldi nesta perspectiva de que a gramática ensinada nas escolas de forma descontextualizada e vazia não promove o ensino de língua portuguesa reflexiva, mas passiva.

Sendo assim, as aulas de língua portuguesa no Ensino Fundamental devem ter como referência a leitura e a produção de textos orais e escritos sem marginalizar a norma do aluno. Diante desse tema cabe- nos algumas reflexões: É realmente importante trabalhar a gramática na escola? Como trabalhar a gramática contextualizada no Ensino Fundamental?

Tais questionamentos são oportunos, uma vez que vários autores têm criticado o ensino de gramática na escola. Destacam-se, dentre esses, Geraldi (1984) e Possenti (1996). Deve-se procurar verificar, no entanto, que modelo de gramática é tão veementemente criticado por esses autores. $\mathrm{Na}$ literatura linguística, podem ser encontrados vários "tipos” de gramáticas, mas é a chamada gramática normativa (conjunto de regras que o usuário deve saber para falar e escrever "corretamente" CÂMARA JR, 1986) que vem sendo alvo das justas críticas dos linguistas.

Geraldi (1984) diz que as concepções de linguagem e de gramática são que determinam todo trabalho em sala de aula. Esse interessantíssimo poema de Drummond aborda o tema da diferença entre a língua falada com tranquilidade pelos alunos e a língua escrita e normatizada ensinada nas escolas. O poeta dá testemunho de sua perturbação diante do "mistério" da língua escrita. Percebemos como fica sugerido o confronto entre o universo solto da vida comum e o mundo do saber representado pela escola. Vejamos: 
Aula de português

\author{
A linguagem \\ na ponta da língua, \\ tão fácil de falar \\ e de entender.
}

A linguagem

na superfície estrelada de letras,

sabe lá o que ela quer dizer?

Professor Carlos Góis, ele é quem sabe,

e vai desmatando

o amazonas de minha ignorância.

Figuras de gramática, esquipáticas, atropelam-me, aturdem-me, seqüestram-me.

Já esqueci a língua em que comia, em que pedia para ir lá fora, em que levava e dava pontapé,

a língua, breve língua entrecortada do namoro com a prima.

O português são dois; o outro, mistério.

(In Andrade-1979)

Travaglia (2008), pontua o seguinte:

O ensino de gramática em nossas escolas tem sido primordialmente prescritivo, apegando-se a regras de gramática normativa [...] tais regras e exemplos são repetidos anos a fio como formas "corretas" e "boas" a serem imitadas na expressão do pensamento. Nas aulas há uma ausência quase total de atividades de produção e compreensão de textos. (TRAVAGLIA, 2008, p. 101).

Pensando nisso, propomos um trabalho diferenciado e que faz parte da realidade dos alunos, colocando o texto como centro da aula de gramática e não como mero "pretexto" para a apresentação de regras gramaticais.

Portanto ao ensinarmos gramática queremos que o aluno domine a língua, para ter uma competência comunicativa nessa língua, mas como diz Geraldi (1991) é preciso entender que dominar uma língua não significa apenas incorporar um conjunto de itens lexicais (o vocabulário)"; aprender um "conjunto de regras de estruturação de enunciados" e aprender " um conjunto de máximas ou princípios" de como construir um texto oral( participando de uma conversação ou não) ou escrito, levando em conta os interlocutores possíveis e os objetivos que se tem ao dizer, bem como a própria 
situação de interação como elementos pertinentes nessa construção e no estabelecimento do efeito de sentido que acontece na interação comunicativa.

Concordamos com Travaglia (2008) quando diz que:

\begin{abstract}
A perspectiva textual tem a possibilidade de fazer com que a gramática seja flagrada em seu funcionamento, evidenciando que a gramática é a própria língua em uso. Isto muda também o conceito de gramática que será usado no ensino de língua materna, pois passa-se a ver como integrando a gramática tudo que é utilizado e/ou interfere na construção e uso dos textos em situações de interação comunicativa e não só o conhecimento de alguns tipos de unidades e regras da língua restritas ao níveis morfológico (classes de palavras, flexão verbal e nominal e as categorias que elas expressam: gênero,número, pessoa, tempo, modo, voz e aspecto) e sintático ( termos da oração, tipos de orações e períodos, regras de concordância e regência, etc). (TRAVAGLIA, 2008, p. 101).
\end{abstract}

Desta maneira ratificamos que o trabalho com gramática no Ensino Fundamental deve promover o ensino da língua e a reflexão sobre esta.

\title{
Conclusão
}

As ideias aqui contidas são reflexões, não acabadas, mas com possibilidades, dentre muitas existentes de se pensar com mais carinho em um trabalho com gramática no Ensino Fundamental de uma maneira reflexiva e construtiva de significados.

Torna-se imprescindível para os professores, portanto, para o profissional da educação, a oportunidade de refletir sobre o trabalho de gramática na escola e sua importância no Ensino Fundamental de forma reflexiva.

\section{Referências}

CÂMARA JR., J. M. Estrutura da língua portuguesa. 16. ed. R. de Janeiro: Vozes,1986.

GERALDI,J. W.Portos de passagem.São Paulo-SP:Martins Fontes,1991.

GERALDI, J. W. Concepções de linguagem e ensino de português. In: O texto na sala de aula: leitura e produção. 2. ed. Cascavel: Assoeste, 1984. p. 41-48.

POSSENTI, S. Por que (não) ensinar gramática na escola. Campinas: Mercado deLetras/ALB, 1996. 
Id on Line Revista Multidisciplinar e de Psicologia

Id on Line Multidisciplinary and Psychology Journal

TRAVAGLIA. Luiz Carlos. Gramática e interação: uma proposta para o ensino de gramática. São Paulo: Cortez, 2008.

\section{Como citar este artigo (Formato ABNT):}

NUNES, G.C.; LUZ, M.A.C. Gramática no Ensino Fundamental: Por uma Pedagogia da Reflexão. Id on Line Revista Multidisciplinar e de Psicologia, Julho de 2016, vol.,10 n.30, Supl 1. p. 383-387. ISSN 1981-1179.

Recebido: $14 / 05 / 2016$

Aceito: 19/05/2016 